\title{
TAXONOMIC CONSIDERATIONS AND AMENDED DESCRIPTION OF Humiriastrum SPIRITU-SANCTI, HuMiriaCEAE
}

\author{
Luiz Carlos da Silva Giordano ${ }^{1}$ \& Claudia Petean Bove ${ }^{2}$
}

\begin{abstract}
(Taxonomic considerations and amended description of Humiriastrum spiritu-sancti, Humiriaceae) An amended description of Humiriastrum spiritu-sancti is presented, highlighting characters of the ovary, style, stigmatic surface, intrastaminal disk and fruit, alongside with the analysis of the pollen morphology. The species is illustrated and several new records increase the extent of its distribution.

Key words: taxonomy, morphology, pollen, Atlantic rain forest.

Resumo

(Considerações taxonômicas e nova descrição de Humiriastrum spiritu-sancti, Humiriaceae) É apresentada uma nova descrição de Humiriastrum spiritu-sancti com ênfase em aspectos morfológicos do ovário, estilete, superfície estigmática, disco intra-estaminal e fruto, além de uma análise morfológica do pólen. A espécie é ilustrada e sua distribuição geográfica é incrementada pela descoberta de novos registros.

Palavras-chave: taxonomia, morfologia, palinologia, floresta pluvial atlântica.
\end{abstract}

\section{INTRODUÇÃO}

The family Humiriaceae comprises eight genera (Duckesia, Endopleura, Humiria, Humiriastrum, Hylocarpa, Sacoglottis, Schistostemon and Vantanea), distributed in the Neotropics, from Nicaragua to southern Brazil, with one species on the west coast of Africa. The name Humiriastrum dates back to Urban (1877), who divided the genus Sacoglottis, based on the number of stamens, into the subgenera Humiriastrum (20 undivided stamens), Schistostemon (20 stamens, the five largest being trifurcate) and Eusacoglottis [=Sacoglottis $]$ (10 stamens). Cuatrecasas (1961) raised these taxa to generic level. Currently, Humiriastrum comprises 16 species, distributed from Costa Rica to southern Brazil (Paraná State).

Bove \& Melhem (2000) performed pollen analysis on 16 of the 20 taxa described in Humiriastrum, concluding that this is a stenopalynous genus, characterised by a polar axis smaller than the equatorial, ie., an oblate spheroidal to suboblate grain, with the single exception of $H$. spiritu-sancti. Bove \&
Melhem (2000) pointed out the resemblance of this taxon with members of the genus Vantanea (following analysis of 20 out of 21 taxa), which is the only genus of the family where the pollen has the polar axis larger than the equatorial, ie., is prolate spheroidal to prolate in shape.

Cuatrecasas (1964) based his description of Humiriastrum spiritu-sancti on a single specimen, the holotype (RB 86212), which presents only very young buds. Our analysis of both the holotype and the isotype (MBML 1279) has shown that both are inadequate to perform a morphological analysis of their reproductive structures, and our attempts to obtain pollen for analysis by the acetolysis method (Erdtman 1952); Wodehouse (1935), did not yield any results. Besides this, the analysis of additional specimens has shown a greater variation in leaf-size in relation to the protologue. The following amended description takes into account vegetative and reproductive structures of more abundant material recently collected, highlighting the presence of fruits, which are distinctive within the genus.

Artigo recebido em 08/2007. Aceito para publicação em 01/2008.

${ }^{1}$ Instituto de Pesquisas Jardim Botânico do Rio de Janeiro, Rua Pacheco Leão 915, 22460-030, Rio de Janeiro, RJ, Brazil. giordano@jbrj.gov.br

${ }^{2}$ Departamento de Botânica, Museu Nacional, Quinta da Boa Vista, 20940-040, Rio de Janeiro, RJ, Brazil. cpbove@ibpinet.com.br 


\section{Materials And Methods}

With the aid of Willd stereoscope and Carl Zeiss optical microscopes, equipped with camera lucida, analysis and drawings were made of buds, flowers and fruits, as well as branchlets and leaves of material deposited in the following herbaria ALCB, CEPEC, CVRD, NY, R and US(as in Holmgren et al. (1990)), identified by Cuatrecasas between 1988 and 1994, and confirmed by the first author of this work. In addition to those, a sample of a sterile specimen from VIC, some fertile material deposited in $\mathrm{R}$ and CVRD were also studied.

\section{RESULTS AND DISCUSSION}

Humiriastrum spiritu-sancti Cuatrec., Ciencia, Mexico 23(4): 137. 1964.

Fig. 1 a-n

Large tree reaching 25-30 $\mathrm{m}$ high, branches glabrous, terminal branches striateexfoliated. Leaves alternate; stipules absent; petiole subterete, $0.6-0.8 \mathrm{~cm}$ long, thick; blade coriaceous, obovate to elliptical-obovate, (3.5-) $9(-0.5) \mathrm{cm}$ long, 2-4.5 cm broad, cuneate toward base, obtuse to slightly retuse at apex, margin entire, chartaceous, sometimes revolute; secondary veins 6-10 pairs. Inflorescences axillary, cymose-corymbose, dichotomous or rarely trichotomous, peduncle glabrous, branches hirtellous, pedicels tomentose-hispidous; bracts deciduous. Sepals obtuse, 0.5-0.6 mm long, carnose, green, glabrous, except on margins; petals subovate, 1.2-3.5 mm long, subcarnose, pale green or whitish, glabrous. Stamens 20; filament thick and flattened, lower part connate, anther dorsifixed, connective rostrate, thecae 2, unilocular, dehiscing by longitudinal slit, pollen grains medium size, $(32 \times 27 \mu \mathrm{m})$, subprolate (polar axis / equatorial axis $=1.17$ ), small polar areas, apocolpium index 0.3-0.49, tricolporate, colpi long, endoaperture rectangular lalongate or quadrangular, sexine microrreticulate, nexine inconspicuous disruptured and curved towards interior of grain near apertures. Intrastaminal disk free, annular, denticulate, $0.4-0.5 \mathrm{~mm}$ high, glabrous. Ovary superior, globose or ovoid, 5 locular, cells uniovulate, glabrous; style erect,
0.5-0.7 mm long, glabrous; stigma 5-lobate, glabrous. Fruits oblong-ellipsoid, $2.5 \times 1.7 \mathrm{~cm}$ diam.; exocarp subcoriaceous; endocarp woody, rugose, 5 foramina around apex, 5 oblong germinal valves on upper half, 1 locule; seed oblong.

Specimens examined: BRAZIL. BAHIA: Ilhéus, Fazenda Barra do Manguinho - ramal no km 10 da rodovia Pontal-Olivença, 5.II.1982, fl., bud, L. A. Mattos Silva et al. 1436 (ALCB, CEPEC, US); Una, Reserva Biológica de Una, 14.IX.1993, fr., A. M. A. Amorim et al. 1391 (CEPEC, NY, R, US). ESPÍRITO SANTO: Santa Tereza, Lombardia, 25.I.1954, bud, G. Dalcomo s.n. (RB 86212 - holotype; MBML 1279 - isotype); Linhares, Reserva Florestal da Companhia Vale do Rio Doce, 8.XI.1977, fl., bud, J. Spada 8/77 (CVRD, US, RB); ibdem, 23.XI.1993, bud, D. A. Folli 2095 (CVRD, RB); ibdem, 2.XII.2003, fl., bud, L. C. Giordano et al. 2678 (RB, CVRD); Conceição da Barra, FLONA Rio Preto, 22.VIII.1995, st., A. Luiza s.n. (VIC 17971).

Humiriastrum spiritu-sancti is a large tree found in the states of Bahia and Espírito Santo, in the Atlantic Rain Forest, generally in primary forest, rarely in secondary vegetation. It is a species that is poorly represented in herbaria, probably due to its restricted occurrence, and is fortunately found in four protected areas (Reserva Biológica de Una, Floresta Nacional Rio Preto, Reserva Natural da Companhia Vale do Rio Doce, and Reserva Biológica Augusto Ruschi). It was initially believed to be endemic to the region of Santa Teresa, Espírito Santo State (Cuatrecasas 1964), but it was subsequently found in Ilhéus and Una (Bahia State) and in Conceição da Barra and Linhares (Espírito Santo State). It is not possible at the moment to confirm whether this species is rare as it may simply be poorly collected because it is a very tall tree with small pale green to whitsh flowers.

Collections of flowering specimens date from the months of November, December, January and February, fruiting in September. This species is locally known as "carne-devaca". It is probably used for its timber.

The genus Humiriastrum has the smallest pollen grains in the family, generally small to medium and of suboblate to spheroidal shape, while $H$. spiritu-sancti presents pollen grains 

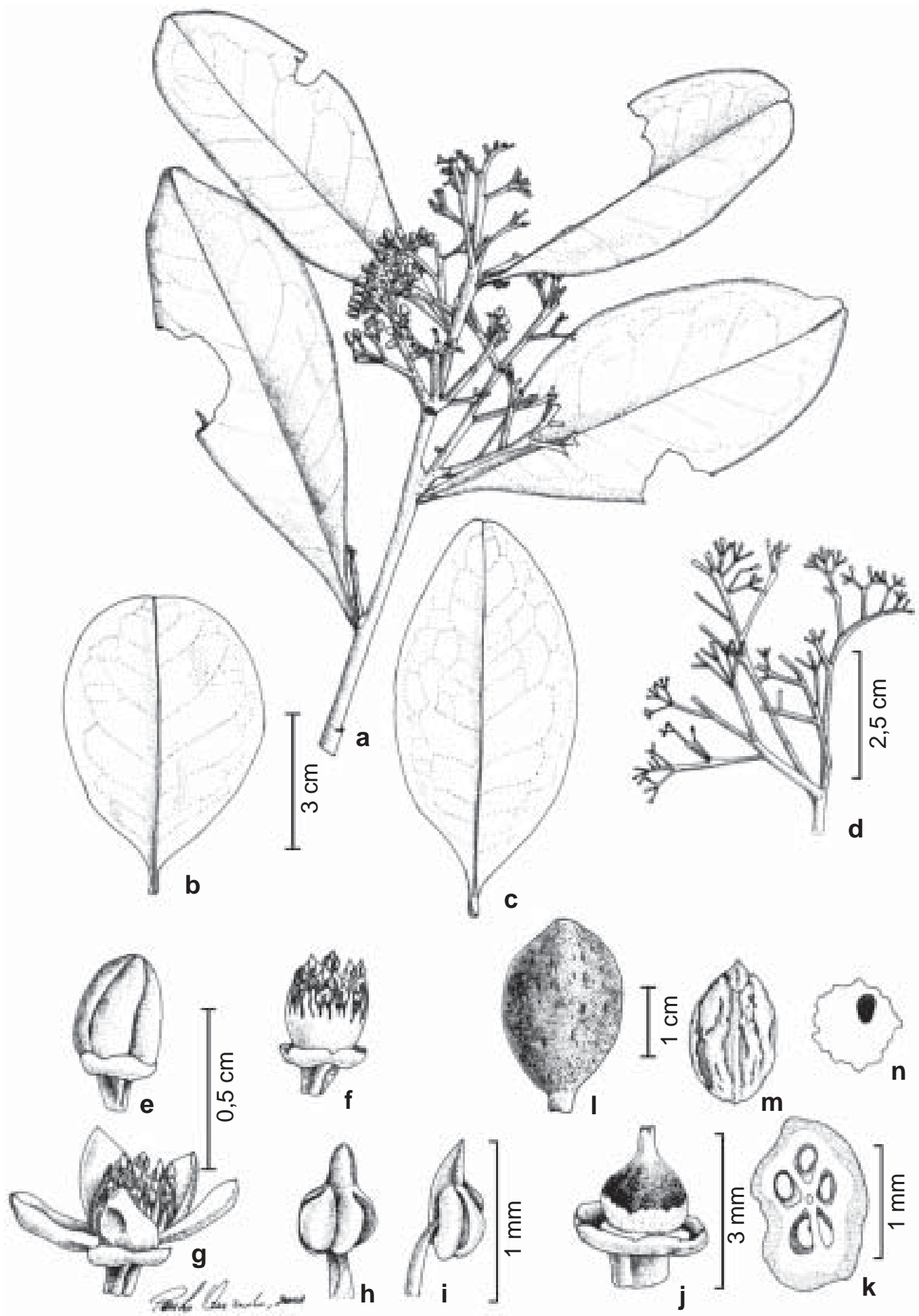

c
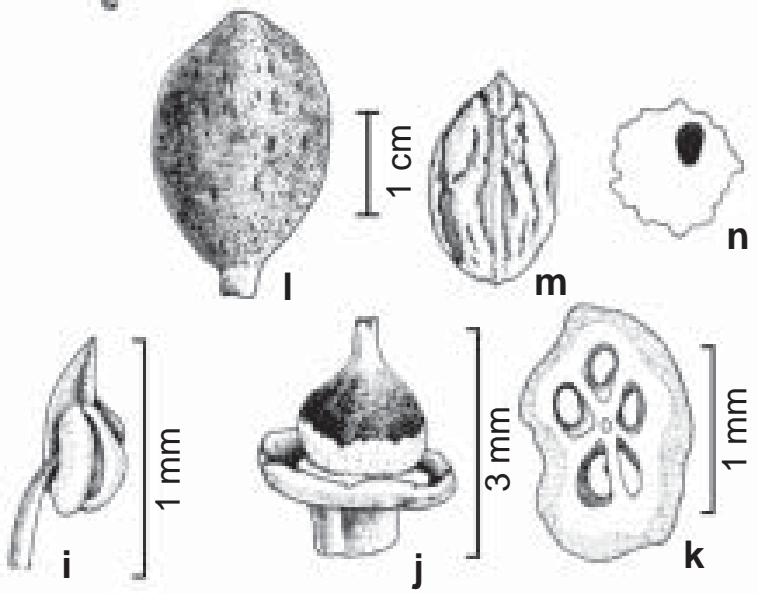

Figure 1 - Humiriastrum spiritu-sancti - a. fertile branch; b, c. leaves; d. inflorescence branch; e. bud; f. bud without petals, showing whorled the stamens whorl; g. flower; h. front view of stamen; i. lateral view of stamen; j. ovary, style, intrastaminal free disk and receptacle; $\mathrm{k}$. ovary; in cross-section; 1 . fruit; m. endocarp; $\mathrm{n}$. endocarp in cross-section. (a, hk Spada 8/77; b Dalcomo s.n., RB 86212 - holotype; c, 1-n Amorim 1391; d-g Mattos Silva 1436) 
of medium size and of subprolate shape, and this character, together with the discontinuity and detachment of the endexine towards the interior of the grain in the proximity of the openings, was believed to be exclusive to the genus Vantanea (Bove \& Melhem 2000).

Contrary to the pollen morphology divergent from what is commonly found within Humiriastrum, the other morphological data coincide with its classification within the genus, especially the endocarp with 5 foramina around the apex, 5 oblong germinal valves on the upper half and only one fertile locule.

\section{ACKNOWLEDGMENTS}

The second author thanks Dra. Therezinha Sant'Ana Melhem for her assistance in interpreting the pollen morphology. We thank the curators of the following herbaria for kindly providing access to their collections: ALCB, CEPEC, CVRD, NY, R RB, US, as well as Coordenação de Aperfeiçoamento de Pessoal do Ensino Superior - CAPES for the travel grant for second author.

\section{REFERENCES}

Bove, C. P. \& Melhem, T. S. 2000. Humiriaceae. Pollen and Spore Flora of the World 22: 1-35.

Cuatrecasas, J. 1961. A taxonomic revision of the Humiriaceae. Contributions from the United States National Herbarium 35(2): 25-214.

1964. Miscelánea sobre Flora Neotrópica, I. Ciencia, Mexico 23(4): 137-151.

Erdtman, G. 1952. Pollen Morphology and Plant Taxonomy. Angiosperms. Stockholm: Almqvist \& Wiksell, 539p.

Holmgren, P. K.; Holmgren, N. H. \& Barnett, L. 1990. Index herbariorum. Part 1: The herbaria of the world. 8ed. New York Botanical Garden, New York, 693p.

Urban, I. 1877. Humiriaceae. In: Martius, C. F. P. von (ed.). Flora brasiliensis. München, Wien, Leipzig, 12(2): 425-454.

Wodehouse, R. P. 1935. Pollen Grains. Their structure, identification and significance in Science and Medicine. Mc Graw-Hill Book Company, New York, 574p. 